\title{
Purple Urine Bag Syndrome: More Than Eyes Can See
}

\author{
Nikos Sabanis ${ }^{\mathrm{a}} \quad$ Eleni Paschou $^{\mathrm{b}} \quad$ Panagiota Papanikolaou $^{\mathrm{a}} \quad$ Georgios Zagkotsis $^{\mathrm{a}}$

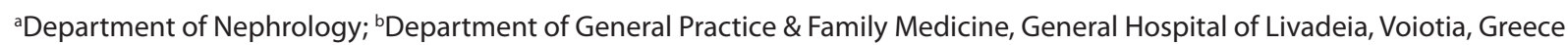

\section{Key Words}

Purple urine bag syndrome • Purple urine discoloration • Urinary tract infection

\begin{abstract}
Background/Aims: Purple urine bag syndrome (PUBS) is an uncommon clinical entity characterized by purple urine discoloration in the setting of urinary tract infections. Pathophysiology of PUBS has been correlated to aberrant metabolism of tryptophan. Multiple predisposing factors have been recognized, namely: female gender, advanced age, constipation, institutionalization, long-term catheterization, dementia and chronic kidney disease. Herein, we present a comprehensive review of all PUBS cases reported in PubMed, focusing on the predisposing factors and the microorganisms related to PUBS. Methods: We performed a search in PubMed database for articles referring to PUBS, published in English, French, Spanish and German from January 1978 until November 2017. The literature recruitment strategy was based on several keywords and Medical Subject Heading combination such as "purple urine bag syndrome" or PUBS or "urine discoloration". The finally selected articles were categorized into case reports/series (88 articles including 112 patients) and studies (10 articles including 134 patients). Demographical data as well as predisposing factors were recorded and further analyzed. Results: According to our findings, mean age of PUBS patients was $78.9 \pm 12.3$ years, $70.7 \%$ were female while $90.1 \%$ were suffering from constipation, $76.1 \%$ were in a bedridden situation, $45.1 \%$
\end{abstract}

\section{KARGER}

Fax +41613061234

E-Mail karger@karger.com

www.karger.com
(C) 2019 The Author(s)

Published by S. Karger AG, Basel Upen access

This article is licensed under the Creative Commons AttributionNonCommercial-NoDerivatives 4.0 International License (CC BYNC-ND) (http://www.karger.com/Services/OpenAccessLicense). NC-ND) (http://www.karger.com/Services/OpenAccessLicense).
Usage and distribution for commercial purposes as well as any distribution of modified material requires written permission. were experiencing long-term catheterization, $42.8 \%$ had been diagnosed with dementia, $14.3 \%$ had recurrent urinary tract infections and $14.1 \%$ were chronic kidney disease patients. $91.3 \%$ of patients presenting with PUBS alkaline urine were observed while the most common microbe in urine cultures was $E$. coli. Conclusions: PUBS is considered benign process in the majority of catheterized patients. Clinicians should be aware of the syndrome that may indicate serious comorbidities.

(c) 2019 The Author(s)

Published by S. Karger AG, Basel

\section{Introduction}

From ancient times, when Hippocrates was credited with being the original uroscopist, until the Victorian era, urine was used as the primary diagnostic tool [1]. Urinary color, smell, sediment even taste could provide important information related to several medical conditions. During the 7th century, the physician Theophilus Protospatharius presented the manuscript "De Urinis" which constituted the first publication exclusively on the subject of urine. The book described a range of urine discoloration and their clinical correlations [2]. In the 12th century, Gilles de Corbeil introduced the matula to assess color and clarity of urine under direct sunlight examination [1].

Urinary discoloration is generally due to changes in urochrome concentration associated with the presence of other pigments. A spectrum of urine colors can be seen 


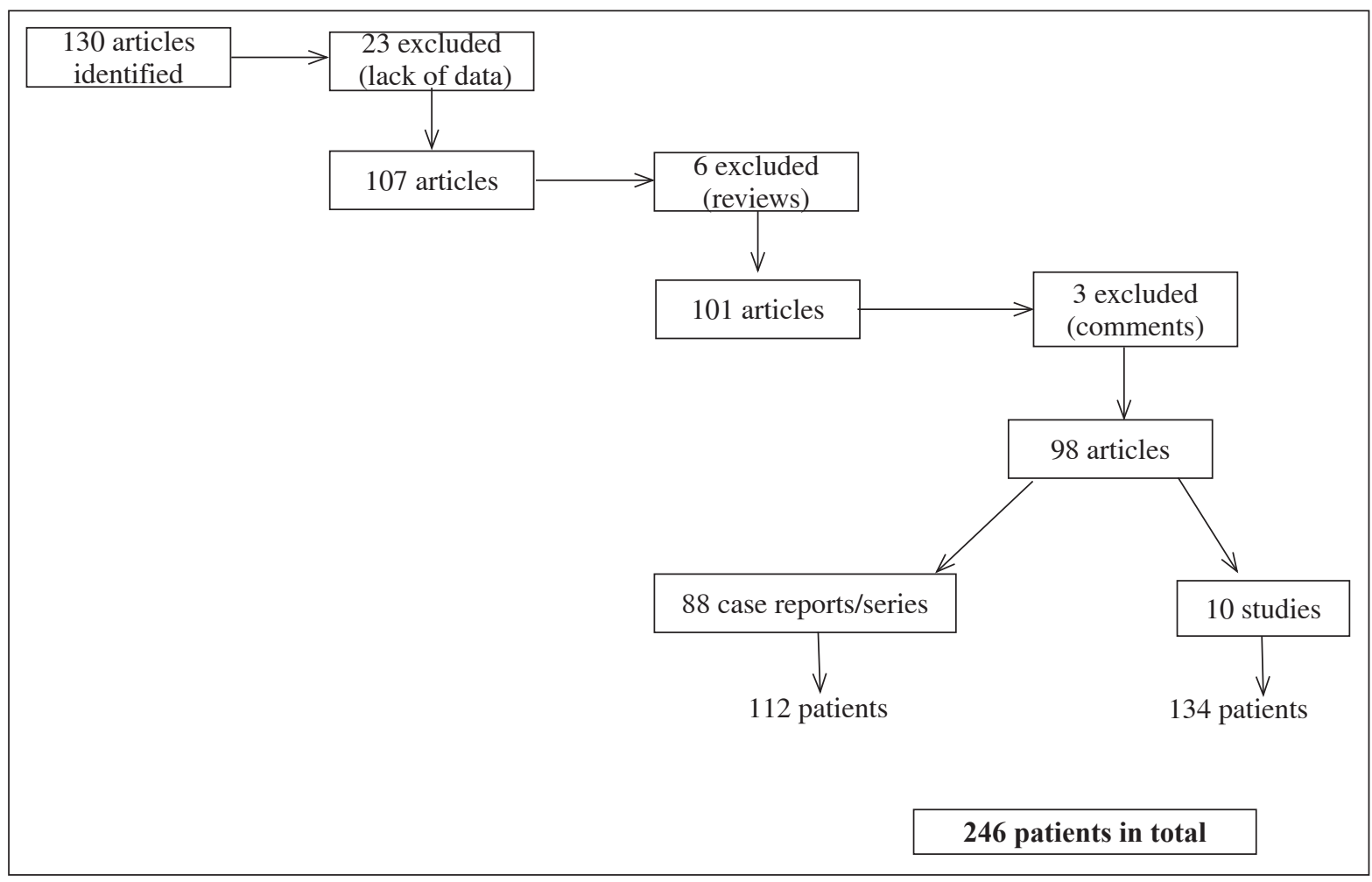

Fig. 1. Literature research process: flow chart.

in urine bags of hospitalized patients and may provide valuable information about presence of infections, medications, poisons, and hemolysis [3].

Urine discoloration is mostly benign, although worrisome to the patient. It usually resolves with removal of the offending agent. Purple urine bag syndrome (PUBS) is referred to a propitious condition caused by increased levels of indigo and indirubin, 2 pigments related to metabolism of the amino-acid tryptophan. Its existence is related mostly to urinary tract infections (UTI), even though other factors seem to play causative role. Among them the commonest are advanced age, female gender, constipation, dementia, bedridden situation, institutionalization, end-stage renal disease, dehydration, chronic catheterization, use of polyvinyl chloride urinary catheter or bag, recurrent UTI, high urinary bacterial counts and alkaline urine. Each factor is associated with PUBS appearance in the setting of certain pathophysiological procedures.

Herein, we present a comprehensive review of all cases of PUBS that are reported in the PubMed. The aim of our study is to record the prevalence of each predisposing factor and to further analyze the pathological mechanism through which the syndrome is manifested. Therefore, we can draw safe conclusions about its recognition and prevention.

\section{Materials and Methods}

\section{Search Strategy}

We performed a search with no date limits of the Medical Subject Heading (MeSH) terms "purple urine bag syndrome" or PUBS or "urine discoloration" in PubMed. Personal files and the bibliography of each identified report were also screened. Articles were selected for review if their title or abstract suggested that they reported individual patient or group data with diagnosis of PUBS.

\section{Selection Criteria}

For the final analysis, we selected reports or studies published as full length articles or letters, which included apparently individuals with PUBS. We exclusively retained well-documented original communications presenting subjects of both sexes and all ages. Reports published in English, Spanish, French or German were included. When more than one article reported on the same patient, only the more comprehensive one was retained. The diagnosis of PUBS was established according to the characterized urine discoloration. 
Table 1. Characteristics of studies $(n=10)$

\begin{tabular}{|c|c|c|c|c|c|c|c|c|c|}
\hline Author & Year & $\begin{array}{l}\text { Country } \\
\text { or region }\end{array}$ & $\begin{array}{l}\text { Type of } \\
\text { study untry }\end{array}$ & $\begin{array}{l}\text { PUBS } \\
\text { patients, n }\end{array}$ & $\begin{array}{l}\text { Mean age, } \\
\text { year }\end{array}$ & $\begin{array}{l}\text { Gender, } \\
\mathrm{M} / \mathrm{F}\end{array}$ & Constipation, $\%$ & Dementia, \% & CKD, \% \\
\hline Dealler et al. & 1989 & UK & Obs & 7 & 84.8 & $0 / 7$ & 100 & 100 & NA \\
\hline Su et al. & 2005 & Taiwan & Obs & 13 & 79.3 & $2 / 11$ & 84.6 & 100 & NA \\
\hline Ga et al. & 2007 & Korea & $\mathrm{C}-\mathrm{C}$ & 16 & 79.5 & $0 / 16$ & NA & NA & NA \\
\hline Lin et al. & 2008 & Taiwan & Obs & 10 & 75.3 & $5 / 5$ & 30 & 90 & 30 \\
\hline Tsimura et al. & 2008 & Japan & $\mathrm{C}-\mathrm{C}$ & 5 & 66.6 & $5 / 0$ & 100 & NA & NA \\
\hline Yang et al. & 2009 & Taiwan & Obs & 10 & 78.9 & $4 / 6$ & 80 & 10 & NA \\
\hline Mumoli et al. & 2013 & Italy & Obs & 41 & 78 & $11 / 30$ & 80.5 & 61 & 60 \\
\hline
\end{tabular}

Obs $=$ Observational study $; \mathrm{C}-\mathrm{C}=$ case control study $; \mathrm{NA}=$ not available.

Data Extraction and Analysis

From each report dealing with PUBS we recorded data on gender, age, risk factors such as dementia, alkaline urine, constipation, history of recurrent UTI, catheterization, institutionalization, existence of chronic kidney disease (CKD) and type of microbe. The literature search and the data extraction were performed independently by 2 investigators (E.P., N.S). Results are given either as frequency or as median.

\section{Results}

The literature search process is summarized in fig. 1 . For the final analysis we selected 88 scientific reports [4-91] published between January 1978 and November 2017 in English $(\mathrm{n}=74)$, Spanish $(\mathrm{n}=7)$, French $(\mathrm{n}=$ $6)$ and German $(n=2)$. They had been reported from the following countries: the United States of America ( $\mathrm{n}=$ $12)$, France $(n=8)$, Taiwan $(n=8)$, Spain $(n=7)$, Japan $(\mathrm{n}=7)$, India $(\mathrm{n}=6)$, United Kingdom $(\mathrm{n}=5)$, Italy $(\mathrm{n}$ $=4)$, Belgium $(n=3)$, Mexico $(n=2)$, Malaysia $(n=2)$, Turkey $(n=2)$, Germany $(n=2)$, Pakistan $(n=2)$, Singapore $(n=2)$, Brunei $(n=2)$, Australia $(n=2)$, Portugal $(\mathrm{n}=2)$, Brazil $(\mathrm{n}=1)$, Colombia $(\mathrm{n}=1)$, Chile $(\mathrm{n}=1)$, Greece $(n=1)$, Bangladesh $(n=1)$, the Netherlands ( $=1)$, Austria $(\mathrm{n}=1)$, Sweden $(\mathrm{n}=1)$, Hong Kong $(\mathrm{n}=$ $1)$ and Canada $(n=1)$. We also extracted data from 10 studies [92-101] that conducted in Taiwan $(\mathrm{n}=4)$, Japan $(\mathrm{n}=3)$, Italy $(\mathrm{n}=1)$, Korea $(\mathrm{n}=1)$ and United Kingdom $(n=1)$ during the years 1989 to 2013 (table 1).

A total of 246 patients (112 case reports, 134 individuals in studies) affected with PUBS were included in the communications, ranging in age from 29 to 99 years (median $78.9 \pm 12.3$ years). Among them $29.3 \%$ were male and $70.7 \%$ female. The prevalence of alkaline urine was up to $91.3 \%$ (only 8 cases described to have acid urine).
Constipation was the main predisposing factor as it was observed in $90.1 \%$ of the cases and dementia was $42.8 \%(n=48)$. A total of $76.1 \%$ of the patients were in a bedridden situation and $37.8 \%$ were institutionalized, while $45.9 \%$ of the patients experienced a long-term catheterization ( $>3$ months). There was a history of recurrent UTI in 16 patients $(14.3 \%)$. In 4 cases, purple urine presented unilaterally in patients with bilateral nephrostomy, 2 patients presented with cystostomy and 5 with suprapubic catheter. Notably, 16 patients were under hemodialysis from a total number of 36 patients who referred with CKD. In 3 patients the syndrome resulted to septic shock and death.

Among the patients recorded $(n=112)$, all of them had evidence of UTI but only in 15 patients fever was noticed $(13.4 \%)$. In 92 patients $(82.1 \%)$ the responsible microbe was identified in a urine culture; $30.4 \%(n=28)$ of them reported with mixed ( $>2$ microbes) culture while $69.6 \%(n=64)$ reported with only one bacteria. The most common microbes identified as the causes of UTI related to PUBS were: Escherichia Coli, Proteus Mirabilis, Klebsiella Pneumoniae, Enterococcus, Pseudomonas Aeruginosa, Providencia Stuartii, Morganella Morgannii, Proteus Vulgaris, Providencia Rettgeri, Streptococcus Faecalis, Enterobacter Cloacae etc. (table 2).

\section{Discussion}

PUBS represents an alarming and distressing condition that is characterized by purple urine discoloration (fig. 2). This clinical entity was firstly referred in 1978 [102]. The estimated prevalence ranges from 8.3 to $42.1 \%$ in different series regarding hospitalized patients [97, 99, 
Table 2. Percentage of type of microbes

\begin{tabular}{lc}
\hline Type of Microbe & Percentage (\%) \\
\hline Escherichia Coli & 20.8 \\
Proteus Mirabilis & 16.2 \\
Klebsiella Pneumoniae & 13.6 \\
Enterococcus spp & 9.1 \\
Pseudomonas Aeruginosa & 9.1 \\
Providencia Stuartii & 5.8 \\
Morganella Morgannii & 5.2 \\
Proteus Vulgaris & 3.2 \\
Providencia Rettgeri & 2.6 \\
Streptococcus Faecalis & 2.6 \\
Enterobacter Cloacae & 1.9 \\
Serratia Marcescens & 1.9 \\
Citrobacter Braakii & 1.3 \\
Alcaligenes spp & 1.3 \\
Citrobacter Freundii & 1.3 \\
Streptococcus Agalactiae & 0.6 \\
Citrobacter Diversus & 0.6 \\
Acinetobacter Baumannii & 0.6 \\
Klabsiella Oxytoca & 0.6 \\
Citrobacter Coser & 0.6 \\
Pseudomonas Testosterona & 0.6
\end{tabular}

Citrobacter Coser
Pseudomonas Testosterona

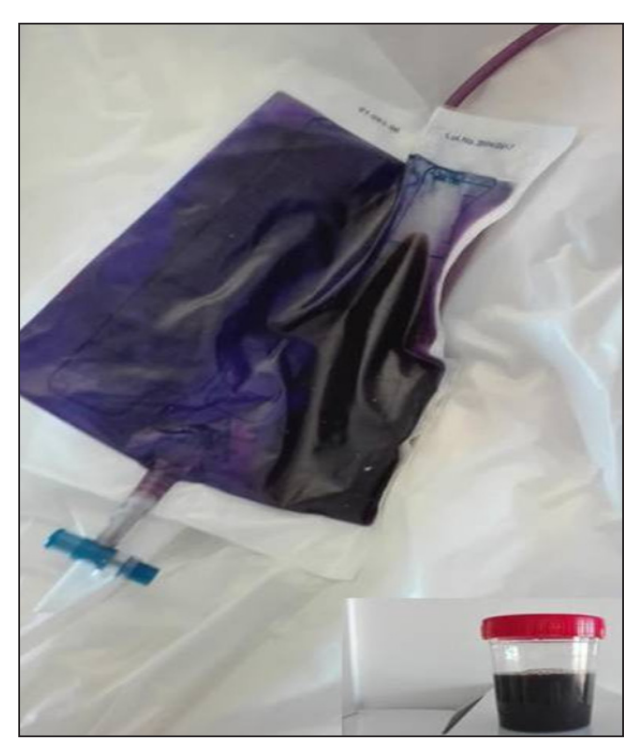

Fig. 2. PUBS picture from personal files.

102] with increasing trends over the last few years [19]. The syndrome can be easily identified and treated but it remains a neglected entity, in spite of the fact that implies a considerable underlying pathology.

Pathophysiology is referred to a chain reaction regarding the metabolism of tryptophan that leads to urinary by-products: indirubin and indigo. Tryptophan is an

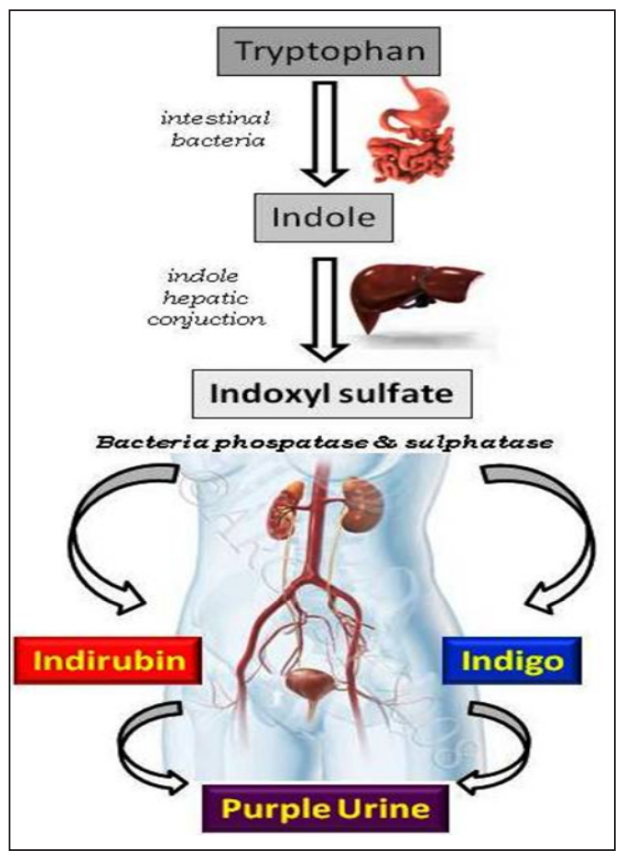

Fig. 3. Metabolism of tryptophan in pathophysiology.

$\alpha$-amino acid used in the biosynthesis of proteins. This amino acid is transferred in the large intestine in order to be metabolized into indole by gut microbiota [103] Afterwards it is diffused into the portal circulation and reaches the liver where it is converted into 3-hydroxyindole through cytochrome P450 2E1 (CYP2E1) [104]. Following that, 3-hydroxyindole is sulfonated through human liver SULT1A1 isoform, leading to indoxyl sulfate formation [105]. Indoxyl sulfate (indican) is excreted in the urine tract. There, under the influence of bacterial enzymes such as sulphatases and phosphatases, especially in an alkaline environment, indican formats 2 pigments: indirubin (red) and indigo (blue) [102]. The mixture of those 2 pigments is responsible for converting urine into purple (fig. 3).

The vast majority of patients with purple urinary catheter bags have been found to have increased levels of urinary indican [101]. Indican, which is a colorless organic compound, is soluble in water and can be easily detected through Obermeyer test [106]. It depicts a toxin that is overproduced under certain conditions such as bacterial overgrowth or altered microbiota (gut dysbiosis), and more specifically in a plethora of chronic diseases, namely, obesity, type 2 diabetes mellitus, chronic constipation, malabsorption syndromes and Parkinson's disease [107]. Nevertheless, there have been some reported 


\begin{tabular}{|ll|}
\hline A: $\quad$ Alkaline urine $\mathrm{pH}$ \\
\hline B: $\quad$ Bedridden- situation \\
\hline C: $\quad$ Constipation \\
\hline E: $\quad$ Dementia \\
\hline F: $\quad$ Female gender \\
\hline G: $\quad$ Growth of bacteria (MUTI) \\
\hline H: $\quad$ Hygiene - long term catheterization \\
\hline
\end{tabular}

Fig. 4. The susceptible patient: The ABCDEFGH rule.

cases of PUBS that are presented without any evidence of indicanuria [87, 89]. In these cases the violet pigment in the urine is thought to be due to the activity of a steroidal or bile-acid conjugate [99].

Numerous factors have been associated with purple discoloration of urine. In accordance with our review, the most important are advanced age, female gender, constipation, dementia, bedridden situation, institutionalization, end-stage renal disease, dehydration, chronic catheterization, use of polyvinyl chloride urinary catheter or bag, recurrent UTI, high urinary bacterial counts and alkaline urine (fig. 4).

Regarding our research, PUBS affects patients with a mean age of 79 years. There are many reasons why elderly people are highly predisposed to the syndrome. Old age is associated with lots of comorbidities, among them dementia, constipation and renal failure can represent independent risk factors for PUBS [93]. Furthermore, lots of elderly people are immobilized or institutionalized, presenting high odds of long-term urinary catheterization. Chronic catheterization, especially when hygiene precautionary measures are not taken into account, is predisposed to UTI that may lead to PUBS [99, 100].

Usually this syndrome comes as a result of UTI even in the absence of dysuria or fever [108]. In these cases, urinary bacteria produce enzymes sulphatase/phosphatase that convert urinary indoxyl sulphate into idirubin and indigo, resulting in urine discoloration [102]. High urinary bacterial count represents an important risk

Purple Urine Bag Syndrome factor according to Mantani et al. [100] who showed that there is a proportional tendency of discoloration of urine bags to the urinary bacterial yield. It is noteworthy that the presence of these bacteria in urine is not always associated with PUBS and no causative relationship between specific bacterial species and PUBS can be documented [100]. Nevertheless, the association between bacteria and PUBS cannot not be excluded since the purple discoloration usually resolves after antibiotics administration and urinary catheters replacement [86, 89, 109].

Most cases $(91.3 \%)$ report PUBS in an alkaline urine environment. Unambiguously, alkaline environment is an important condition for the catalysis of indoxyl into indigo and indirubin [48]. However, alkaline urine is a promoting but not an obligatory requisition for PUBS since few reports of the syndrome have been exhibited in patients with slightly acidic urine (pH 6.0-6.5) [7, 29, 55, 66, 71, 75, 82, 100].

PUBS is frequently associated with constipation. According to our findings $90.1 \%$ of patients that presented with PUBS were suffering from chronic constipation. Chronic constipation is characterized by reduced gut motility and prolonged transit time. Those phenomena lead to bacterial overgrowth in bowel lumen [14], where the conversion of tryptophan to indole takes place. On the other hand, patients suffering from constipation usually use laxatives or long-term application of suppository bisacodyl. Those treatments are able to cause damage to colorectal mucosa and changes of normal intestinal microbiota, leading to the preferential growth of certain bacterial species which produce indigo as a by-product [110].

In terms of gender, it seems that PUBS affects women predominantly, since the study revealed that $70.7 \%$ of PUBS patients were female. This is mostly explained as female urethra is particularly prone to colonization by colonic gram negative bacilli, owing to its proximity to the anus, its short length and its termination beneath the labia [100]. Contrariwise, male specific factors such as zinc, a potent antibacterial agent that is secreted by the prostate, act protectively [111]. Consequently, it is well understood why female gender represents a highly recognized risk factor.

Last but not least, in CKD, elevated levels of indican have been demonstrated in several studies. In patients with CKD, production and absorption of noxious by-products can contribute to malnutrition, inflammation and uremic toxicity [112]. Uremia results in the depletion of key protein constituents in the colonic epithelial tight junction, a phenomenon that can account for the impaired structural 
and functional intestinal barrier [113]. Simultaneously, in uremic milieu, qualitative and quantitative modifications of gut microbiota are observed. These alterations are intensified, due to constipation which is more frequent in end-stage renal disease patients under hemodialysis as a result of insufficient hydration, phosphate-binders intake and strict dietary restrictions concerning fruit and vegetables. In combination, impaired intestinal epithelial barrier and alteration of the intestinal microbiota can lead to endotoxemia and accumulation of the gut-derived uremic toxins such as indican [115].

Furthermore, in CKD patients, the reduced glomelular filtration rate causes higher serum and urine concentration of indican [114]. Especially in CKD patients under hemodialysis, removal of indican is limited as it is highly bound to albumin. Consequently, serum indoxyl sulphate concentration is further increased [115], suggesting that patients with CKD under hemodialysis have higher possibility of developing indicanuria leading to PUBS. Correspondingly, it is observed that in hemodialysis patients without sufficient residual diuresis, the urinary tract is a significant reservoir for infections [118] and another reason for why they are more prone to PUBS.

\section{Conclusions}

During the last decades, life expectancy has been increased. This fact drives the world population in demographic aging, associated with high prevalence of chronic diseases such as dementia, diabetes mellitus and CKD. Correspondingly, high incidence of resistant infections is noted worldwide due to irrational use of antibiotics.

PUBS is usually connected to UTI. It is a benign condition that can easily be identified without expensive investigations. Precautionary hygiene measures of catheterized patients and preservation of general well-being are essential in prevention of the syndrome. It is also necessary to strengthen the management of antibiotics in the context of an individualized approach. Clinicians of primary and secondary health involved in geriatric care should be of great awareness about the syndrome that may indicate serious underlying comorbidities.

\section{References}

1 Armstrong JA: Urinalysis in Western culture: a brief history. Kidney Int 2007;71:384-387.

2 Jasin J: The transmission of learned medical literature in the middle English Liber uricrisiarum. Med Hist 1993;37:313-329.

3 Viswanathan S: Urine bag as a modern day matula. ISRN Nephrol 2013;2013:215690.

4 Golzarri MF, Hernaiz-Leonardo JC, Diaz-Gonzalez A, Velazquez-Acosta C, VilarCompte D: Purple urine bag syndrome: an uncommon manifestation of urinary tract infection. Gac Med Mex 2017;153:273-275.

5 Macias Guzman I, Espildora Hernandez J, Ramirez Bollero JM: Purple urine bag syndrome. Rev Clin Esp 2017;217:433.

6 Wan Sulaiman WA, Hoo FK, Inche Mat LN: An intriguing case of purple urine bag syndrome. Am J Med Sci 2017;353:e9.

7 Ficher KN, Araujo AA, Houly SG, Lins PR, Silva M Jr, Gois AF: Purple urine bag syndrome: case report for Streptoccocus agalactiae and literature review. J Bras Nefrol 2016; 38:470-472.

8 Kocoglu H, Yildirim B, Okuturlar Y, Hursitoglu M, Harmankaya O: Purple urine bag syndrome in a male patient with chronic hemodialysis. Balkan Med J 2016;33:717-718.
9 Lin J, Hlafka M, Vargas O, Bhattarai M: Recurrent purple urine bag syndrome presenting with full spectrum of disease severity: case report and review of literature. CEN Case Rep 2016;5:144-147.

10 Demelo-Rodriguez P, Galan-Carrillo I, Del Toro-Cervera J: Purple urine bag syndrome. Eur J Intern Med 2016;35:e3-e4.

11 Neweling F, Janssens U: Purple urine bag syndrome in a patient with bilateral nephrostomy. Med Klin Intensivmed Notfmed 2016;111:731-733.

12 Khalid L, Ali I, Wahid K, Khan AU, Fawad S: Purple urine bag syndrome. J Coll Physicians Surg Pak 2016;26:863-864.

13 Barman B, Lyngdoh M, Lynrah KG, Warjri SB: Purple urine bag syndrome. J Assoc Physicians India 2016;64:91-92.

14 Aubert CJ, Alvarado Lavado FJ, Sanchez Calso A, Gonzalez Gonzalez J: Purple urine in the bag. Semergen 2016;42:e25-26.

15 Tul Llah S, Khan S, Dave A, Morrison AJ, Jain S, Hermanns D: A case of purple urine bag syndrome in a spastic partial quadriplegic male. Cureus 2016;8:e552.
16 Faridi MS, Rahman MJ, Mibang N, Shantajit N, Somarendra K: Purple urine bag syndrome - an alarming situation. J Clin Diagn Res 2016;10:PD05-06.

17 Sriramnaveen P, Reddy YS, Sridhar A Kishore CK, Manjusha Y, Sivakumar V: Purple urine bag syndrome in chronic kidney disease. Indian J Nephrol 2016;26:67-68.

18 Redwood R, Medlin J, Pulia M: Elderly man with dark urine. Purple urine bag syndrome. Ann Emerg Med 2015;66:436-440. Abubacker NR, Jayaraman SM, R K, Sivane-

19 san MK, Mathew R: Purple urine bag syndrome. J Clin Diagn Res 2015;9:OD01-02. Mohamed Faisal AH, Shathiskumar G, Nu-

20 rul Izah A: Purple urine bag syndrome: case report from a nursing home resident with a false alarm of urosepsis. Med J Malaysia 2015;70:265-266.

Mondragon-Cardona A, Jimenez-Canizales

21 CE, Alzate-Carvajal V, Bastidas-Rivera F, Sepulveda-Arias JC: Purple urine bag syndrome in an elderly patient from Colombia. J Infect Dev Ctries 2015;9:792-795.

22 Tur FC, Zafer N, Hocaoglu N: Purple urine bag syndrome. Emerg Med J 2015;32:347. 
23 Kenzaka T: Purple urine bag syndrome in a patient with a urethral balloon catheter and a history of ileal conduit urinary diversion. Korean J Intern Med 2015;30:420.

24 Van Keer J, Detroyer D, Bammens B: Purple urine bag syndrome in two elderly men with urinary tract infection. Case Rep Nephrol 2015;2015:746981.

25 Alex R, Manjunath K, Srinivasan R, Basu G: Purple urine bag syndrome: time for awareness. J Family Med Prim Care 2015;4:130131.

26 Evans R, Allan M, Walsh S: Purple urinary bag syndrome. BMJ Case Rep 2014; 2014:bcr2014207483.

27 Chassin-Trubert C AM: Purple urine bag syndrome: report of one case. Rev Med Chil 2014;142:1482-1484.

28 Delgado G, Martinez-Resendez M, Camacho-Ortiz A: Purple urine bag syndrome in end-stage chronic kidney disease. J Bras Nefrol 2014;36:542-544.

29 Restuccia MR, Blasi M: A PUBS case in a palliative care unit experience. Case Rep Oncol Med 2014;2014:169782.

30 Agapakis D, Massa E, Hantzis I, Paschoni E, Satsoglou E: Purple urine bag syndrome: a case report of an alarming phenomenon. Hippokratia 2014;18:92-94.

31 Koh KS, Chong VH: Purple urine bag syndrome (PUBS): an unusual and rare manifestation of a common condition. Ann Acad Med Singapore 2013;42:700-701.

32 Ungprasert P, Ratanapo S, Cheungpasitporn W, Kue APP, Bischof EF Jr: Purple urine bag syndrome. Clin Kidney J 2013;6:344.

33 Wolff N, Indaburu I, Muller F, Mariescu Depaire N: Purple urine bag syndrome.... Prog Urol 2013;23:538-539.

34 Canavese C, Airoldi A, Quaglia M, Barbe MC, Brustia M, Vidali M, Bagnati M, Andreone S, Corra T, Sciarrabba C, Bellomo G, Stratta P: Recognizing purple bag syndrome at first look. J Nephrol 2013;26:465-469.

35 Duff ML: Case report: purple urine bag syndrome. J Emerg Med 2013;44:e335-336.

36 Yaqub S, Mohkum S, Mukhtar KN: Purple urine bag syndrome: a case report and review of literature. Indian J Nephrol 2013;23:140-142.

37 Mohamad Z, Chong VH: Purple urine bag: think of urinary tract infection. Am J Emerg Med 2013;31:265.e5-6.

38 Bhattarai M, Bin Mukhtar H, Davis TW, Silodia A, Nepal H: Purple urine bag syndrome may not be benign: a case report and brief review of the literature. Case Rep Infect Dis 2013;2013:863853.

39 Al Montasir A, Al Mustaque A: Purple urine bag syndrome. J Fam Med Prim Care 2013; 2:104-105.

40 Iglesias Barreira R, Albinana Perez MS, Rodriguez Penin I, Bilbao Salcedo J: Purple urine bag syndrome in two institutionalised patients. Rev Esp Geriatr Gerontol 2013; 48:45-47.
41 Meekins PE, Ramsay AC, Ramsay MP: Purple urine bag syndrome. West J Emerg Med 2012;13:499-500.

42 Bocrie OJ, Bouchoir E, Camus A, Popitean L, Manckoundia P: Purple urine bag syndrome in an elderly subject. Braz J Infect Dis 2012;16:597-598.

43 Dominguez Alegria AR, Velez Diaz-Pallares M, Moreno Cobo MA, Arrieta Blanco F, Bermejo Vicedo T: Purple urine bag syndrome in elderly woman with nutritional supplements. Nutr Hosp 2012;27:2130-2132.

44 Cantaloube L, Lebaudy C, Hermabessiere S, Rolland Y: Pastel in the urine bag. Geriatr Psychol Neuropsychiatr Vieil 2012;10:5-8.

45 Tejada Evans AD, Ortega-Sanchez G, Moreno Guillen S: Purple urine syndrome. Rev Clin Esp 2012;212:e6

46 Keenan CR, Thompson GR 3rd: Purple urine bag syndrome. J Gen Intern Med 2011; 26:1506.

47 Zeier MG, Lee KG, Tan CS: An elderly nursing home resident with unusual urine bag discoloration. NDT Plus 2011;4:445-446.

48 Peters P, Merlo J, Beech N, Giles C, Boon B, Parker B, Dancer C, Munckhof W, Teng HS: The purple urine bag syndrome: a visually striking side effect of a highly alkaline urinary tract infection. Can Urol Assoc J 2011; 5:233-234.

49 Fernandez de Orueta L, Esteban Fernandez J, Perez Caballero G, Melero Bermejo JA, Regajo Gallego R, Martinez Carrilero J: Purple urine. Nefrologia 2011;31:489-490.

50 Ferrara F, D’Angelo G, Costantino G: Monolateral purple urine bag syndrome in bilateral nephrostomy. Postgrad Med J 2010;86:627.

51 Su HK, Lee FN, Chen BA, Chen CC: Purple urine bag syndrome. Emerg Med J 2010; 27:714.

52 Siu G, Watanabe T: Purple urine bag syndrome in rehabilitation. PM R 2010;2:303306.

53 Caldeira D, Colaco ML, Heitor S, Braganca $\mathrm{N}$ : Deep purple urine. Intern Med 2010; 49:2369.

54 Al-Sardar H, Haroon D: Purple urinary bag syndrome. Am J Med 2009;122:e1-2.

55 Tasi YM, Huang MS, Yang CJ, Yeh SM, Liu CC: Purple urine bag syndrome, not always a benign process. Am J Emerg Med 2009; 27:895-897.

56 van Iersel M, Mattijssen V: Purple urine bag syndrome. Neth J Med 2009;67:340-341.

$57 \mathrm{Wu} \mathrm{HH}$, Yang WC, Lin CC: Purple urine bag syndrome. Am J Med Sci 2009;337:368.

58 Pillai BP, Chong VH, Yong AM: Purple urine bag syndrome. Singapore Med J 2009; 50:e193-194.

59 Mumoli N, Cei M: A case of purple urine. QJM 2009;102:147.

60 Yamazaki Y, Kobatake K: The purple urine bag syndrome. BMJ Case Rep 2009;

61 2009:bcr08.2009.2154.

Khellaf A, Medjahed S, Dupont T, Venet R, Sebbane G: Purple urine bag syndrome. Presse Med 2008;37:1687-1689.
62 Liolios AC, Woess E, Lhotta K: Purple urine bag syndrome (PUBS). NDT Plus 2008; 1:365-366

63 Chung SD, Liao CH, Sun HD: Purple urine bag syndrome with acidic urine. Int J Infect Dis 2008; 12:526-527.

64 Tan CK, Wu YP, Wu HY, Lai CC: Purple urine bag syndrome. CMAJ 2008;179:491.

65 Chiang HC, Huang MS, Cheng CC: An experience providing home care to a victim of cerebral vascular accident and purple urine bag syndrome. Hu Li Za Zhi 2008;55:98-104.

66 Ahrens D, Scherer M: Purple urine bag syndrome. Dtsch Med Wochenschr 2008; 133:889-890.

67 Pillai RN, Clavijo J, Narayanan M, Zaman K An association of purple urine bag syndrome with intussusception. Urology 2007;70:812. e1-2.

68 Lee J: Images in clinical medicine. Purple urine. New Engl J Med 2007;357:e14.

69 Lazimy Y, Delotte J, Machiavello JC, Lallement M, Imbenotte M, Bongain A: Purple urine bag syndrome: a case report. Prog Urol 2007; 17:864-865.

70 Ting IW, Wang R, Wu VC, Hsueh PR, Hung KY: Purple urine bag syndrome in a hemodialysis patient. Kidney Int 2007;71:956.

71 Bar-Or D, Rael LT, Bar-Or R, Craun ML, Statz J, Garrett RE: Mass spectrometry analysis of urine and catheter of a patient with purple urinary bag syndrome. Clin Chim Acta 2007;378:216-218.

72 Gautam G, Kothari A, Kumar R, Dogra PN: Purple urine bag syndrome: a rare clinical entity in patients with long term indwelling catheters. Int Urol Nephrol 2007;39:155-156.

73 Komiyama A: Purple diaper syndrome in geriatrics. J Am Geriatr Soc 2006;54:1954-1955.

74 Beunk J, Lambert M, Mets T: The purple urine bag syndrome. Age Ageing 2006;35:542

75 Tang MW: Purple urine bag syndrome in geriatric patients. J Am Geriatr Soc 2006; 54:560-561.

76 Achtergael W, Michielsen D, Gorus FK, Gerlo E: Indoxyl sulphate and the purple urine bag syndrome: a case report. Acta Clin Belg 2006;61:38-41.

77 Wang IK, Ho DR, Chang HY, Lin CL, Chuang FR: Purple urine bag syndrome in a hemodialysis patient. Intern Med 2005;44:859-861.

78 Rohaut B, Bachmeyer C, Lecomte I, Ravet N, Grateau G: A urine bag turns purple. Rev Med Interne 2005;26:666-667.

79 Ribeiro JP, Marcelino P, Marum S, Fernandes AP, Grilo A: Case report: purple urine bag syndrome. Crit Care 2004;8:R137.

80 Fain-Ghironi N, Le Gonidec P, Schaeffer M: Purple urine bag syndrome. Presse Med 2003;32:985-987.

81 Ihama Y, Hokama A: Purple urine bag syndrome. Urology 2002;60:910.

82 Ollapallil J, Irukulla S, Gunawardena I: Purple urine bag syndrome. ANZ J Surg 2002; 72:309-310. 
83 de Bruyn G, Eckman CD, Atmar RL: Photo quiz. Purple discoloration in a urinary catheter bag. Clin Infect Dis 2002;34:210, 285-216.

84 Al-Jubouri MA, Vardhan MS: A case of purple urine bag syndrome associated with Providencia rettgeri. J Clin Pathol 2001;54:412.

85 Coquard A, Martin E, Jego A, Capet C, Chassagne PH, Doucet J, Bercoff E: Purple urine bags: a geriatric presentation of lower urinary tract infection. J Am Geriatr Soc 1999; 47:1481-1482.

86 Ishida T, Ogura S, Kawakami Y: Five cases of purple urine bag syndrome in a geriatric ward. Nihon Ronen Igakkai Zasshi 1999; 36:826-829.

87 Nobukuni K, Kawahara S, Nagare H, Fujita Y: Study on purple pigmentation in five cases with purple urine bag syndrome. Kansenshogaku Zasshi 1995;69:1269-1271.

88 Matsuo H, Ishibashi T, Araki C, Sakamaki H, Mazume H, Ueki Y, Miyake S, Tominaga Y, Toyomura K: Report of three cases of purple urine bag syndrome which occurred with a combination of both E. coli and M. morganii. Kansenshogaku Zasshi 1993;67:487-490.

89 Stott A, Khan M, Roberts C, Galpin IJ: Purple urine bag syndrome. Ann Clin Biochemi 1987;24:185-188.

90 McSherry JA: The purple bag syndrome. Can Fam Physician 1980;26:1410-1411.

91 Buist NR: Purple urine bags. Lancet 1978; 1:883-884.

92 Mumoli N, Vitale J, Brondi B, Basile V, Cei M: Purple urine-bag syndrome in a department of medicine. J Am Geriatr Soc 2013; 61:2240-2241.

93 Yang CJ, Lu PL, Chen TC, Tasi YM, Lien CT, Chong IW, Huang MS: Chronic kidney disease is a potential risk factor for the development of purple urine bag syndrome. J Am Geriatr Soc 2009;57:1937-1938.

94 Shiao CC, Weng CY, Chuang JC, Huang MS, Chen ZY: Purple urine bag syndrome: a community-based study and literature review. Nephrology (Carlton) 2008;13:554-559.

95 Muneoka K, Igawa M, Kurihara N, Kida J, Mikami T, Ishihara I, Uchida J, Shioya K, Uchida S, Hirasawa H: Biochemical and bacteriological investigation of six cases of purple urine bag syndrome (PUBS) in a geriatric ward for dementia. Nihon Ronen Igakkai Zasshi 2008;45:511-519.
96 Tsumura H, Satoh T, Kurosaka S, Fujita T, Matsumoto K, Baba S: Clinical characteristics in patients with purple urine bag syndrome. Hinyokika Kiyo 2008;54:185-188.

97 Lin CH, Huang HT, Chien CC, Tzeng DS, Lung FW: Purple urine bag syndrome in nursing homes: ten elderly case reports and a literature review. Clin Interv Aging 2008; 3:729-734.

98 Ga H, Park KH, Choi GD, Yoo BI, Kang MC, Kim SM, Lee EJ, Park ST, Park CH: Purple urine bag syndrome in geriatric wards: two faces of a coin? J Am Geriatr Soc 2007; 55:1676-1678.

99 Su FH, Chung SY, Chen MH, Sheng ML, Chen CH, Chen YJ, Chang WC, Wang LY, Sung KY: Case analysis of purple urine-bag syndrome at a long-term care service in a community hospital. Chang Gung Med J 2005;28:636-642.

100 Mantani N, Ochiai H, Imanishi N, Kogure T, Terasawa K, Tamura J: A case-control study of purple urine bag syndrome in geriatric wards. J Infect Chemother 2003;9:53-57.

101 Dealler SF, Belfield PW, Bedford M, Whitley AJ, Mulley GP: Purple urine bags. J Urol 1989;142:769-770.

102 Dealler SF, Hawkey PM, Millar MR: Enzymatic degradation of urinary indoxyl sulfate by Providencia stuartii and Klebsiella pneumoniae causes the purple urine bag syndrome. J Clin Microbiol 1988;26:21522156.

103 Rossi M, Johnson DW, Morrison M, Pascoe EM, Coombes JS, Forbes JM, Szeto CC, McWhinney BC, Ungerer JP, Campbell KL: Synbiotics easing renal failure by improving gut microbiology (SYNERGY): a randomized trial. Clin J Am Soc Nephrol 2016; 11:223-231.

104 Banoglu E, Jha GG, King RS: Hepatic microsomal metabolism of indole to indoxyl, a precursor of indoxyl sulfate. Eur J Drug Metab Pharmacokinet 2001;26:235-240.

105 Banoglu E, King RS: Sulfation of indoxyl by human and rat aryl (phenol) sulfotransferases to form indoxyl sulfate. Eur J Drug Metab Pharmacokinet 2002;27:135-140.

106 Gore SN: A Simple Method for Detecting and Estimating Indican in the Urine by Means of the Cotton-Wool Plug Test. Ind Med Gaz 1924;59:393-396.
107 Cassani E, Barichella M, Cancello R, Cavanna $\mathrm{F}$, Iorio $\mathrm{L}$, Cereda $\mathrm{E}$, Bolliri $\mathrm{C}$, Zampella Maria P, Bianchi F, Cestaro B, Pezzoli G: Increased urinary indoxyl sulfate (indican): new insights into gut dysbiosis in Parkinson's disease. Parkinsonism Relat Disord 2015;21:389-393.

108 Domenech MV, Calatroni M, Esposito P, Serpieri N, La Porta E, Estienne L, Caramella E, Dal Canton A, Rampino T: "Deep" purple urine bag syndrome: physiopathology and clinical implications. G Ital Nefrol 2016;33.

109 Umeki S: Purple urine bag syndrome (PUBS) associated with strong alkaline urine. Kansenshogaku Zasshi 1993; 67:1172-1177.

110 Saunders DR, Haggitt RC, Kimmey MB, Silverstein FE: Morphological consequences of bisacodyl on normal human rectal mucosa: effect of a prostaglandin E1 analog on mucosal injury. Gastrointest Endosc 1990; 36:101-104.

111 Fair WR, Parrish RF: Antibacterial substances in prostatic fluid. Prog Clin Biol Res 1981;75A:247-264.

112 Vaziri ND: CKD impairs barrier function and alters microbial flora of the intestine: a major link to inflammation and uremic toxicity. Curr Opin Nephrol Hypertens 2012; 21:587-592.

113 Vaziri ND, Yuan J, Rahimi A, Ni Z, Said H, Subramanian VS: Disintegration of colonic epithelial tight junction in uremia: a likely cause of CKD-associated inflammation. Nephrol Dial Transplant 2012;27:2686-2693.

114 Niwa T, Takeda N, Tatematsu A, Maeda $\mathrm{K}$ : Accumulation of indoxyl sulfate, an inhibitor of drug-binding, in uremic serum as demonstrated by internal-surface reversed-phase liquid chromatography. Clin Chem 1988;34:2264-2267.

115 Vanholder R, De Smet R, Glorieux G, Argiles A, Baurmeister U, Brunet P, Clark W, Cohen G, De Deyn PP, Deppisch R, Descamps-Latscha B, Henle T, Jorres A, Lemke HD, Massy ZA, Passlick-Deetjen J, Rodriguez M, Stegmayr B, Stenvinkel P, Tetta C, Wanner C, Zidek W: Review on uremic toxins: classification, concentration, and interindividual variability. Kidney Int 2003;63:1934-1943. 